\title{
Pertanggunguayaban Pidana TERHADAP KEMATIAN PETINJU AKIBAT KEALPAAN PENYELENGGARA
}

\author{
\begin{tabular}{l|l} 
Umar Hadi & Bulak Banteng Baru GG Anggrek
\end{tabular} \\ umar_hadi@gmail.com 1 No 118 Surabaya
}

\begin{abstract}
This article discusses the criminal accountability of the boxer's death due to negligence of the organizer under the Islamic criminal law perspective. Criminal responsibility for the death of a boxer due to negligence of the organizer in Criminal Code (KUHP) is including negligence which results in the death of another person who carried out by the manager, game inspector, ring doctor, and the referee who lead and participate in a game. For this case, they will be exposed by Article 359 of the Criminal Code and Chapter XII of forgery in particular in Article 263 Paragraph (1) of Criminal Code. In the Islamic criminal law perspective, this is related to the error murder called (qatl al-khata) which contains 3 elements, namely: first, an act that causes the death of someone; second, the occurrence of the act is because of error; and three, a causal relationship between the fault act with the victim's death. Based on this, the perpetrator is fined by 100 camels or in its equivalent.
\end{abstract}

Keywords: Accountability, crime, boxer, neglect.

\begin{abstract}
Abstrak: Artikel ini membahas tentang pertanggungjawaban pidana terhadap kematian petinju akibat kealpaan penyelenggara perspektif hukum pidana Islam. Pertanggungjawaban pidana terhadap kematian petinju akibat kealpaan penyelenggara dalam KUHP adalah termasuk kelalaian yang mengakibatkan kematian orang lain yang dilakukan olah manager, inspektur pertandingan, dokter ring, dan wasit yang memimpin dan berperan dalam pertandingan, yang mana meraka akan terkena dalam pasal 359 KUHP dan Bab XII tentang pemalsuan surat khususnya pada pasal 263 ayat (1) KUHP. Dalam hukum pidana Islam hal ini berkaitan dengan pembunuhan kesalahan yang disebut (qatl al-khata') yang mengandung 3 unsur yaitu; pertama; perbuatan yang menyebabkan kematian, kedua; terjadinya perbuatan itu karena kesalahan, Ketiga; adanya hubungan sebab akibat antara perbuatan kesalahan dengan kematian korban. Berdasarkan hal tersebut, maka pelaku dikenakan sanksi denda 100 ekor unta atau setara dengan hal tersebut.
\end{abstract}

Kata Kunci: Pertanggungjawaban, pidana, petinju, kealpaan. 


\section{Pendahuluan}

Tujuan pembangunan nasional di antaranya memajukan kesejahteraan umum dan mencerdaskan kehidupan bangsa. ${ }^{1}$ Untuk mencapai hal tersebut diperlukan modal yang memadai. Salah satu modal yang harus dimiliki untuk tujuan mewujudkan tujuan pembangunan nasional di atas adalah kesehatan, karena tanpa kesehatan yang memadai dari rakyat adalah mustahil untuk mewujudkan tujuan pembangunan nasional tersebut. Untuk mewujudkan kesehatan tersebut salah satunya adalah dengan olahraga. ${ }^{2}$ Menurut Undang-Undang Nomor 3 tahun 2005 tentang sistem keolahragaan nasional, olahraga dibedakan menjadi 5 kelompok di antaranya adalah: ${ }^{3}$

1. Olahraga pendidikan adalah pendidikan jasmani dan olahraga yang dilaksanakan sebagai bagian proses pendidikan yang teratur dan berkelanjutan untuk memperoleh pengetahuan, kepribadian, keterampilan, kesehatan, dan kebugaran jasmani.

2. Olahraga rekreasi adalah olahraga yang dilakukan oleh masyarakat dengan kegemaran dan kemampuan yang tumbuh dan berkembang sesuai dengan kondisi dan nilai budaya masyarakat setempat untuk kesehatan, kebugaran, dan kegembiraan.

3. Olahraga prestasi adalah olahraga yang membina dan mengembangkan olahragawan secara terencana, berjenjang, dan berkelanjutan melalui kompetisi untuk mencapai prestasi dengan dukungan ilmu pengetahuan dan teknologi keolahragaan.

4. Olahraga amatir adalah olahraga yang dilakukan atas dasar kecintaan atau kegemaran berolahraga.

5. Olahraga profesional adalah olahraga yang dilakukan untuk memperoleh pendapatan

Di antara kelima kelompok olahraga tersebut, yang dapat dijadikan tumpuan untuk mendapatkan penghasilan adalah olahraga profesional. Tak jarang para olahragawan dari kelompok olahraga yang lain tertarik untuk berpindah jalur ke jalur olahraga profesional. Memang dalam kenyataan penghasilan yang diperoleh dari jenjang

\footnotetext{
${ }^{1}$ Alinea keempat pembukaan Undang-Undang Dasar Republik Indonesia tahun 1945

2 Olahraga adalah segala kegiatan yang sistematis untuk mendorong, membina, serta mengembangkan potensi jasmani, dan nasionalis. Undang-Undang Sstem Keolahragaan Nasional (Jakarta: Sinar Grafika, 2006), 3.

${ }^{3}$ Ibid., 14 .
} 
olahraga profesional akan berbanding lurus dengan prestasi yang diraih oleh atlet itu sendiri.

Ancaman cedera jika atlet berkarir di jenjang profesional tidak menghalangi atlet untuk terus berkarir dengan alasan sebagai sumber penghasilan. Tidak jarang pula cidera yang dialami oleh atlet olahraga profesional tersebut bukan hanya cidera ringan, tetapi juga berat dan tak jarang pula yang berujung kepada kematian.

Salah satu cabang olahraga profesional adalah olahraga tinju, sebagai olahraga yang tergolong keras, cabang olahraga tinju sangat rentan terhadap cedera, meskipun sudah dibentengi dengan aturan pertandingan yang ketat, cedera pada olahraga tinju profesional masih saja bisa terjadi. Tercatat dari tahun 1990 hingga saat ini sebanyak 15 orang atlet tinju profesional meninggal dunia akibat bertanding dan 9 orang mengalami cidera berat, mulai dari gegar otak ringan sampai kerusakan jaringan sel otak permanen. ${ }^{4}$ Lebih memprihatikan lagi, dari kematian 15 orang atlet tinju Profesional Indonesia tersebut hingga kini belum ada yang diproses secara hukum. ${ }^{5}$

Untuk penjelasan yang lebih terperinci, kasus kematian petinju akibat bertanding digambarkan dalam bentuk tabel di bawah ini :

Tabel Kematian Petinju di Indonesia ${ }^{6}$

\begin{tabular}{|c|l|l|c|l|}
\hline No & \multicolumn{1}{|c|}{ Korban } & \multicolumn{1}{c|}{ Lawan } & Tahun & \multicolumn{1}{|c|}{ Kota } \\
\hline 1 & Bonggok kendi & Bisenti santoso & 1990 & Bontang \\
\hline 2 & Yance semagun & Mahmud & 1993 & Jakarta \\
\hline 3 & Akbar maulana & Budiarso & 1995 & Jakarta \\
\hline 4 & Dipo saloko & Roy saragih & 2000 & Jakarta \\
\hline 5 & Bayu yong iray & Herianto kalam & 2000 & Belawan \\
\hline 6 & Jhon namlitu & Hasan purba & 2001 & Bekasi \\
\hline 7 & M. alfarisi & Khong tawat ora & 2001 & Cibinung \\
\hline 8 & Doni maramis & Steven kalalo & 2001 & Manado \\
\hline 9 & $\begin{array}{l}\text { Johanes } \\
\text { pranciscus }\end{array}$ & Slamet nizar & 2003 & Jakarta \\
\hline 10 & Mula sinaga & Ashan tourino & 2003 & Medan \\
\hline 11 & Antonius moses & Kaichon poravin & 2004 & Jakarta \\
\hline
\end{tabular}

\footnotetext{
${ }^{4} \mathrm{http} / /$ search.jawapos.com/indeks.php?act=detail-s\&f-sarch=fadly\%20kasim\& id231884.25 Mei 2009 (12:30:15)

${ }^{5} \mathrm{http} / / 2$. kompas.com/ver1/olahraga/0703/22/u51240.htm 25-05-2009 (13:00:30)

${ }^{6} \mathrm{http}: / /$ search.jawapos.com/indeks.php?act=detail_s\&f_search=fadly\%20kasim \&id=231884
} 


\begin{tabular}{|l|l|l|l|l|}
\hline 12 & Jack ryan & Samsul hidayat & 2004 & Purwokerto \\
\hline 13 & Hendrik bira & Mones arepas & 2005 & Jakarta \\
\hline 14 & Padly kasim & Jibril soamole & 2006 & Manado \\
\hline 15 & Anis dwi kasim & Irfan bone & 2007 & Jakarta \\
\hline
\end{tabular}

Dalam pasal 28 ayat 1 UU No. 4 Tahun 2004 tentang kekuasaan kehakiman diatur bahwasanya, Hakim wajib menggali, mengikuti dan memahami nilai-nilai hukum dan rasa keadilan yang hidup dalam masyarakat. Sudah saatnya pihak kepolisian turun tangan karena ini merupakan kematian petinju yang kesekian kalinya, tanpa ada penyelesaian dan dikhawatirkan kalau Polisi tidak bertindak akan muncul korban berikutnya di bawah naungan KTI Pusat, serta menyelidiki siapa saja yang harus bertanggung jawab, baik itu manajer, dokter ring, inspektur pertandingan serta petinju lawan.

Dalam KUHP, pertanggungjawaban pidana pada hakekatnya mengadung makna pencelaan pembuat (subjek hukum) atas tindak pidana yang telah dilakukannya. Oleh karena itu, pertanggungjawaban pidana mengandung di dalamnya pencelaan objektif dan pencelaan subjektif. Dalam arti secara objektif si pelaku telah melakukan tindak pidana (perbuatan terlarang atau melawan hukum dan diancam pidana menurut hukum yang berlaku) dan secara subjektif, si pelaku patut dicela atau dipermasalahkan atau dipertanggungjawabkan atas tindakan pidana yang dilakukannya itu, sehingga ia patut dipidana. Pengertian subjek tindak pidana meliputi 2 hal, yaitu

1. Siapa yang melakukan tindak pidana (pelaku delik) ${ }^{7}$

2. Siapa yang dapat mempertanggung jawabkan.

Hal ini bergantung dari cara atau sistem pertanggungjawaban pidana yang diperintahkan oleh Undang-undang. Disini perlu dibedakan antara istilah tindak pidana dan pertanggungjawaban pidana. Tindakan pidana adalah perbuatan yang dilarang oleh suatu aturan hukum dimana disertai ancaman yang berupa pidana tertentu. Tindak pidana lebih khusus kepada perbuatan, (yaitu suatu keadaan atau kejadian yang ditimbulkan oleh kelakuan seseorang). Dalam tindak pidana ada dua keadaan konkrit: Pertama, adanya kejadian tertentu dan kedua, adanya orang yang berbuat sehingga menimbulkan kejadian tertentu.

\footnotetext{
${ }^{7}$ Wirjono Prodjodikoro, Asas-Asas Hukum Pidana di Indonesia (Bandung: Eresco, 1989), 55.
} 
Sedangkan pertanggungjawaban pidana tidak cukup hanya dilakukannya perbuatan pidana saja, di samping itu harus ada kesalahan. Jadi orang dapat dikenakan ancaman pidana tidak hanya karena tindak pidananya saja melainkan juga karena adanya kesalahan.

Sedangkan menurut Hukum Pidana Islam, pertanggungjawaban adalah pembebanan seseorang dengan akibat perbuatan atau tidak adanya perbuatan yang dikerjakan dengan kemauan sendiri, di mana orang tersebut mengetahui maksud dan akibat dari perbuatanya itu.

Pertanggungjawaban didasarkan kepada tiga hal ${ }^{8}$ :

1. Adanya perbuatan yang dilarang.

2. Perbuatan itu dikerjakan dengan kemauan sendiri.

3. Pelaku mengetahui akibat perbuatan tersebut.

Jadi, apabila terdapat tiga hal tersebut maka terdapat pula pertanggungjawaban, sedangkan faktor-faktor yang mengakibatkan adanya pertanggungjawaban pidana adalah perbuatan maksiat yaitu mengerjakan perbuatan yang dilarang oleh shara' atau sebaliknya meninggalkan apa yang diperintahkan oleh shara'. Untuk adanya pertanggungjawaban ini masih memerlukan dua syarat lagi yaitu adanya idrâk dan ikhtiâr. Pertanggungjawaban pidana dalam Islam bertingkattingkat disesuaikan dengan niat si pelaku, dengan demikian maka pertanggungjawaban itu juga bisa berubah-ubah tergantung niat dari si pelaku yaitu bisa sengaja, menyerupai sengaja, keliru, dan yang disamakan dengan keliru.

\section{Penyelenggaraan Pertandingan Tinju}

Kata tinju adalah terjemahan dari kata Inggris "boxing" atau "Pugilism". Kata Pugilism berasal dari kata Latin, pugilatus. Pinjaman dari kata Yunani Pugno, Pignis, Pugnare, yang menandakan segala sesuatu yang berbentuk kotak atau " $B o x "$ dalam bahasa Inggrisnya. Tinju Manusia yang mana apabila kalau terkepal akan berbentuk seperti kotak. Kata Yunani pugno berarti tangan terkepal seperti tinju, siap untuk pugnos, berkelahi, bertinju. ${ }^{9}$

Asal mula tinju sebagai olahraga berangkat dari pertarungan adu budak di Amerika. Dua orang Negro diadu dalam lingkaran manusia hingga salah satunya ambruk. Kadang untuk mempersangar, tangan

\footnotetext{
${ }^{8}$ A. Hanafi, Asas-Asas Hukum Pidana Islam (Jakarta: Bulan Bintang, 1990), 121.

${ }^{9} \mathrm{http} / / /$ www.boxing-indonesia.com/2008/05/asal-mula-istilah-ring.html 30-10-2009 (18:00:16)
} 
kedua petarung diberi pecahan beling. Otomatis darah lebih cepat mengalir dan sobekan daging terlempar kemana-mana. Jelas kepentingan atas pertarungan ini bukanlah untuk membuat kedua budak tadi sehat, tapi untuk berjudi.

Kini bertinju jauh lebih beradab. Peraturan demi peraturan dibuat. Ahli-ahli medis juga dilibatkan untuk menyumbangkan saran tentang "Bertinju yang Sehat". Akibatnya, jumlah ronde diperkecil. Ketentuan TKO dan KO dipertajam. Wasit-wasit diatur kesehatan psikologisnya. ${ }^{10}$

Kriteria olahragawan menurut pasal 1 angka 7 No 3 tahun 2005 undang-undang keolahragaan adalah pengelohragaan yang mengikuti pelatihan secara teratur dan mencapai prestasi. Sedang mengenai hak dan kewajiban olahragawan di atur dalam pasal 55 dan 57 undang-undang keolahragaan. Menurut pasal 57 undang-undang nomor 3 tahun 2005 tentang Sistem Keolahragaan Nasional, yang mengatur tentang kewajiban seorang olahragawan dan petinju profesional adalah ${ }^{11}$ :

1. Menjunjung tinggi nilai luhur dan nama baik bangsa dan Negara Kesatuan Republik Indonesia.

2. Mengedepankan sikap sportifitas dalam setiap kegiatan yang dilaksanakan.

3. Ikut menjaga upaya pelestarian lingkungan hidup.

Ketentuan dalam PP 18/1984, Olahraga Profesional Nomor 18 Tahun 1984 Pasal $4:{ }^{12}$

1. Untuk menjadi olahragawan profesional, setiap olahragawan wajib mendapat persetujuan secara tertulis dari Badan.

2. Persetujuan sebagaimana dimaksud dalam ayat (1) hanya diberikan kepada olahragawan yang memenuhi syarat-syarat sebagai berikut:

a. Berusia 18 (delapan belas) tahun, dan setinggi-tingginya 28 (dua puluh delapan) tahun;

b. Dalam keadaan sehat jasmani dan rohani berdasarkan keterangan dokter yang ditunjuk badan;

c. Menjadi anggota perkumpulan organisasi induk keolahragaan amatir;

\footnotetext{
${ }^{10} \mathrm{http}: / /$ sports.groups.yahoo.com/group/tinju/message/615 30-10-2009

${ }^{11}$ Departemen RI, Undang-undang Keolahragaan No 3 Tahun 2005.

${ }^{12}$ Peraturan Pemerintah No 18 tahun 1984 tentang Olahraga Professional, 3.
} 
d. Pernah mewakili Indonesia dalam olimpiade, Pekan Olahraga Asia, Pekan Olahraga Asia Tenggara, atau menjadi juara nasional;

e. Mendapat rekomendasi dari organisasi induk cabang keolahragaan;

f. Badan berhak mencabut persetujuan sebagaimana dimaksud dalam ayat (1) apabila olahragawan profesional melakukan perbuatan yang bertentangan dengan jiwa sportivitas, melakukan perbuatan yang melanggar kesusilaan, atau melakukan perbuatan yang bertentangan dengan peraturan olahraga profesional.

Peraturan pemerintah Nomor 18 tahun 1985 telah menetapkan bahwa setiap petinju profesional harus melalui jenjang tinju amatir dan paling tidak mereka petinju terbaik diamatir pada kelasnya. Seorang petinju profesional tergabung dalam suatu sasana berkewajiban berlatih setiap hari. Hal ini bertujuan untuk menjaga kondisi fisiknya agar supaya tidak mengalami penurunan ketika akan bertanding. Petinju profesional juga harus berlatih secara intensif minimal tiga bulan sebelum diadakan pertandingan, hal ini dilakukan untuk menjamin bahwa petinju profesional yang akan bertanding benar-benar siap dari segi fisik maupun mental bertandingnya. Ketika seorang petinju profesional bertanding, dia harus bertanding secara sportif dalam artian dia harus memukul lawan di daerah legal yang diperbolehkan unuk dipukul dan teknik bertinju yang benar.

\section{Ketentuan Penyelenggaraan Pertandingan}

Pengaturan secara khusus bidang keolahragaan di Indonesia di atur dalam Undang-Undang No 3 Tahun 2003 tentang Sistem Keolahragaan Nasional dan khusus untuk keolahragaan profesional diatur dalam Peraturan Pemerintah Nomor 18 Tahun 1984 tentang Olahraga Profesional. ${ }^{13}$

Dalam penyelengaraan sebuah pertandingan tinju profesional ada beberapa tahapan yang harus dilalui:

Pertama, inisiatif ${ }^{14}$ Pengadaan pertandingan tinju profesional berasal dari promotor tinju atau penyelenggara selaku penyandang dana untuk menggelar suatu pertandingan tinju. Selanjutnya promotor

\footnotetext{
${ }^{13}$ Departemen RI, Peraturan Pemerintah Nomor 18 Tahun 1984.

${ }^{14}$ hhtp:/www2.kompas.com/kompas-cetak/0404/06/or/953162.html 13-11-2009.
} 
tersebut akan bekerjasama mencari dan bekerjasama dengan penantang tanding atau match maker yang mana dalam hal ini bertindak sebagai even organizer dari promotor. Setelah ada kesepakatan kerjasama antara promotor dengan promotor match maker, maka match maker kemudian mencari petinju yang akan dipertandingkan apabila petinju tersebut setuju kemudian membuat kontrak pertandingan dengan petinju tersebut dan dengan manajernya ${ }^{15}$.

Setelah kontrak pertandingan telah dibuat dan ditanda tangani, promotor melalui match maker kemudian mengajukan ijin pertandingan kepada Komisi Tinju Indonesia selaku organisasi olahraga tertinggi di Indonesia yang menaungi tinju profesional di Indonesia. Apabila pertandingan tinju tersebut memperebutkan gelar juara, maka pengajuan izinya harus kepada pengurus pusat komisi tinju profesional di Indonesia. Tetapi kalau bukan merupakan partandingan perebutan juara maka izinya cukup melalui pengurus daerah atau Propinsi Komisi Tinju Indonesia. Pengajuan izin pertandingan tersebut harus pula menyertakan sejumlah uang dari promotor kepada Komisi Tinju Indonesia sebagai jaminan atas pemenuhan pembayaran kontrak pertandingan antara promotor dengan petinju yang akan bertanding beserta manajernya. Pengajuan ijin tersebut harus sudah masuk kepada Komisi Tinju Indonesia paling lambat lima hari sebelum pertandingan dilaksanakan. Hal ini dimaksud agar Komisi Tinju Indonesia memiliki waktu yang cukup untuk mengkoreksi tentang kelengkapan administrasi dan menyiapkan panitia yang akan bertugas pada pertandingan tersebut.

Jika pertandingan disetujui, maka Komisi Tinju Indonesia akan mengangkat inspektur pertandingan untuk mengawasi jalanya pertandingan, mulai dari persiapan sampai dengan akhir pertandingan. Setelah ada inspektur pertandingan maka tanggung jawab promotor terhadap petinju yang akan bertanding beralih kepada inspektur pertandingan.

Inspektur pertandingan kemudian akan memeriksa kelengkapan administrasi pertandingan, mulai dari pemeriksaan lisensi atau ijin bertinju di kancah profesional, buku rekor tanding atau biasa disebut record book, dan surat pernyataan dari kedua petinju yang akan bertanding yang di ketahui oleh manajernya bahwa mereka tidak pernah terpukul jatuh atau biasa di sebut knock down baik dalam pertandingan

${ }^{15}$ http://www.jawapos.co.id/halaman/index.php?act=detail\&nid=75593 15-11-2009. 
maupun dalam latihan. Selanjutnya inspektur pertandingan akan kembali memeriksa kembali kesehatan dari kedua petinju yang akan bertanding yang dilakukan oleh dokter ring yang akan bertugas pada pertandingan dan melakukan timbang badan pada kedua petinju. Hasil pemeriksaan kesehatan tersebut harus menyatakan bahwa petinju yang akan bertanding harus dalam keadaan sehat dan layak bertanding yang dalam istilah tinju disebut A-1.

Dokter yang memeriksa kesehatan kedua petinju tidak boleh merekomendasikan petinju yang bukan dalam keadaan A-1 untuk bertanding dan sekaligus mencegah cidera yang akan terjadi jika petinju tersebut bertanding dalam kondisi yang tidak fit. Setelah pemeriksaan administrasi selesai, inspektur pertandingan akan menunjuk petugas yang akan membantu jalanya pertandingan meliputi wasit, hakim, dokter ring, pencatat waktu, pencatat hasil, petugas ring, dan lainya yang biasa disebut official ring ${ }^{16}$

Selanjutnya adalah pengurusan ijin kepada Badan Pengawas Pengendali Olahraga Profesional (BP2OPI) selaku badan pengawas olahraga profesional di Indonesia. Selanjutnya BP2OPI akan memeriksa segala hal yang berhubungan dengan administrasi dan persiapan dari pertandingan tersebut. Pemeriksaan yang sangat penting yang dilakukan oleh BP2OPI adalah pemeriksaan kesehatan sebelum pertandingan dilakukan. Jika hasil pemeriksaan tersebut menyatakan petinju yang akan bertanding dalam keadaan A-1 maka BP2OPI maka akan mengijinkan pertandingan tersebut ${ }^{17}$. Sebaliknya, jika BP2OPI menyatakan bahwa petinju yang akan bertanding salah satunya atau keduanya tidak dalam keadaaan A-1 maka pertandingan tidak boleh dilaksanakan.

Adapun syarat yang diterapkan dalam pertandinga tinju adalah: ${ }^{18}$

1. Tidak boleh memukul didaerah dan cara yang ilegal.

2. Tidak boleh memukul didaerah dan cara yang legal.

Mengenai daerah tubuh mana yang merupakan daerah legal dan ilegal dalam pertandingan tinju profesional tidakdi jelaskan secara rinci dalam rules and regulation. Dalam pasal 75 rules and regulation hanya dijelaskan mengenai bentuk-bentuk pelanggaran keras yang dilarang

\footnotetext{
${ }^{16}$ Emha Ainun Najib, Bola-Bola Kultural(Yogyakarta: Prima Pustaka, 1993), 61.

${ }^{17}$ A. Robbani (Wasit), Wawancara, 7 Mei 2009.

${ }^{18} \mathrm{BPHN}, 120$.
} 
untuk dilakukan dalam pertandingan tinju. Bentuk-bentuk pelanggaran tersebut adalah:

1. Memukul di sebelah bawah sabuk;

2. Memukul, lawan jatuh yang sedang bangkit dari jatuh;

3. Memegang lawan dengan satu tangan dan memukulnya dengan tangan yang lain;

4. Memegang atau dengan sengaja terus mendekap;

5. Mendorong lawan keliling ring atau kearah tali ring untuk memukul lawan yang tanpa daya karena lawan menyandar ketali ring dan tidak jatuh;

6. Menggumul dan berbuat kasar ditali ring ;

7. Menyeruduk dengan kepala;

8. Dengan sengaja jatuh tanpa di pukul dengan maksud mengghindar pukulan lawan;

9. Dengan sengaja memukul tubuh sebelah atas ginjal; ${ }^{19}$

Pengaturan dalam pasal tersebut adalah merupakan adopsi rules and regulation badan tinju dunia World Boxing Council (WBC). Adanya aturan tersebut adalah untuk menghindari resiko cidera pada pertandingan tinju profesional, karena menurut pandangan medis jika harus melakukan pertandingan tinju dengan menggunakan teknik pelanggaran seperti di atas, maka besar kemungkinan timbul resiko cidera atau bahkan kematian petinju lawan ${ }^{20}$. Dalam kenyataan teknisnya, apabila salah satu petinju menggunakan teknis pelanggaran tersebut akan dikenakan sanksi organisasi mulai dari yang ringan yaitu dikalahkan dengan cara didiskualifikasi, sampai sanksi yang terberat yaitu sekorsing.

Berdasarkan surat edaran Komisi Tinju Indonesia nomor 026/KTIP/II/2004 menyebutkan beberapa petunjuk tambahan kapan sebuah pertandinag tinju harus segera dihentikan ketika sedang berlangsung. Beberapa petunjuk tersebut adalah;

1. Pertandingan dimana salah satu petinju pada ronde-ronde awal tidak memberikan perlawanan keputusan adalah no contest.

2. Pertandingan dimana salah satu atau kedua petinju tidak memiliki dasar dan teknik berrtinju sesuai dengan aturan dan peraturan, keputusannya.

\footnotetext{
${ }^{19}$ WBC. Rules and Regulations, 10.
}

${ }^{20}$ Ibid., 11. 
a. Diskualifikasi, apabila dalam hal ini hanya salah satu petinju yang tidak memiliki dasar dan teknik bertinju profesional.

b. No contest, apabila keduanya tidak memiliki dasar dan teknik bertinju profesional.

3. Pertandingan, di mana salah satu petinju sengaja atau tidak sengaja berulangkali memukul belakang kepala lawan, namun sebelumnya wasit perlu memberikan peringatan terlebih dahulu kepada petinju/pelatih disudut ring yaitu apabila masih memukul belakang kepala, pertandingan akan dihentikan dan akan didiskualifikasi.

4. Pertandingan dimana dokter sudah memberikan aba-aba tanda merah harus segera dihentikan.

5. Peraturan-peraturan lain sesuai petunjuk WBC atau badan tinju dunia lainya yang pernah disampaikan sebelumnya tetap berlaku dan diperhatikan.

6. Apabila ada intervensi atau ancaman dari luar yang dapat mengakibatkan konsentrasi seseorang wasit menjadi terganggu maka perlu segera melaporkan inspektur pertandingan untuk diteruskan kepihak berwajib. Ketidaktegasan seorang wasit untuk mengambilkan keputusan tidak boleh terganggu. ${ }^{21}$

Berdasarkan surat edaran tersebut, secara normal seorang wasit berkewajiban menghentikan pertandingan. Ketika menghadapi situasi seperti di atas, ia tidak segera menghentikan pertandingan, maka wasit telah melalaikan apa yang telah menjadi kewajibanya.

\section{Para Pihak yang Ada dan Berperan dalam Pelaksanaan Pertandingan}

Dalam pertandingan tinju ada banyak pihak yang berperan dalam sebuah pertandingan tinju profesional. Dalam undang-undang Nomor 3 tahun 2005 tentang Sistem Keolahragaan dan Peraturan Pemerintah Nomor 18 tahun 1984 tentang Olahraga Profesional serta rules and regulations yang ada pada Anggaran Dasar dan Anggaran Rumah Tangga Komisi Tinju Indonesia (KTI), selaku induk organisasi olahraga profesional di Indonesia, mengadopsi aturan dari badan tinju dunia Oriental and Pacific Boxing Federation (OPBF), yang merupakan lembaga terpenting dalam tinju dunia.

Diantara pihak yang berperan dalam olahraga tinju adalah:

1. Olahragawan, yang mana dalam hal ini petinju profesional.

\footnotetext{
${ }^{21}$ Didik Endro Purwoleksono, Diktat Hukum Pidana, 5.
} 
Dan diatur dalam dalam pasal 55 ayat (3) undang-undang keolahragaan, yang menyatakan bahwa setiap Olahragawan profesional mempunyai beberapa hak yaitu ${ }^{22}$ :

a. Didampingi oleh, antara lain manager, pelatih tenaga medis, psikolog, dan ahli hukum.

b. Mengikuti semua kejuaraan sesuai dengan tingkatan dan kemampuan.

c. Mendapatkan pembinaan dan pengembangan dari induk organisasi cabang olagraga, oganisasi olahraga profesional, dan

d. Mendapatkan pendapatan yang layak.

2. Induk Organisasi Cabang Olahraga

Pengaturan mengenai pengertian dari induk organisasi cabang olahraga diatur dalam pasal 1 angka 25 undang-undang keolahragaan yang menyebutkan; induk organisasi cabang olahraga adalah organisasi yang membina, mengembangkan, dan mengkoordinasikan satu cabang/jenis olahraga atau gabungan organisasi olahraga dari satu jenis olahraga yang merupakan anggota federasi cabang olahraga internasional yang bersangkutan

Di dalam rules and regulations Komisi Tinju Indonesia, penyebutan organisasi olahraga disebut nama KTI, yang definisinya adalah badan yang mengendalikan tinju profesional di setiap negara. Jadi tugas induk organisasi adalah membina, mengembangkan dan mengkoordinasikan olahraga yang menjadi bidangnya wadah bagi olahraga yang dinaunginya.

3. Tenaga Kerja Keolahragaan

Pengaturan mengenai siapa saja, persyaratan, dan tugas dari tenaga keolahragaan secara umum diatur dalam Pasal 63 Undang-undang keolahragaan. Dalam Pasal 63 ayat (1) disebutkan:

"Tenaga keolahragaan terdiri atas pelatih, guru/dosen, wasit, juri, manajer, promoter, administrator, penyuluh, instruktur, tenaga medis dan para medis, ahli gizi, ahli biomekanika, psikolog atau sebutan lain sesuai kekhususannya serta berpartisipasi dalam menyelenggarakan kegiatan olah raga. ${ }^{.23}$

Dari ketentuan tersebut dapat ditarik kesimpulan bahwa yang dimaksud dengan tenaga keolahragaan adalah orang-orang yang

\footnotetext{
$22 \mathrm{Ibid}, 20$.

${ }^{23}$ Departemen RI, Undang-undang Keolahragaan Nomor 3 Tahun 2005. Sistem Keolahragaan Nasional, 19.
} 
membantu olahragawan dalam hal ini petinju profesional untuk melakukan profesinya. Mengenai persyaratan untuk menjadi tenaga keolahragaan diatur dalam Pasal 63 ayat (2) yang menyebutkan :

"Tenaga keolahragaan yang bertugas dalam setiap organisasi olahraga dan/atau lembaga olahraga wajib memilki kualifikasi dan sertifikasi kompetisi yang dikeluarkan oleh induk organisasi cabang olahraga yang bersangkutan dan/atau instansi pemerintah yang berwenang".

Sedangkan tugas dari tenaga keolahragaan diatur dalam Pasal 63 ayat (3) yang menyebutkan :

"Tenaga keolahragaan bertugas menyelenggarakan atau melakukan kegiatan keolahragaan sesuai dengan bidang keahlian dan/atau kewenangan tenaga keolahragaan yang bersangkutan".

Beranjak dari ketentuan tersebut, pengertian tentang tenaga keolahragaan mulai dari siapa, syarat, dan tugas dari tenaga keolahragaan itu sendiri adalah terlalu umum pengertiannya.

Pengertian yang lebih khusus diatur dalam Rule and Regulations yang ada pada Anggaran Dasar dan Anggaran Rumah Tangga induk organisasi tinju profesional di Indonesia dalam hal ini adalah Komisi Tinju Indonesia. Di dalam Rule and Regulations tersebut diatur lebih jelas mengenai siapa saja tenaga keolahragaan beserta hak dan kewajiban. Tenaga keolahragaan sebagaimana yang dimaksud dalam Pasal 63 ayat (1) undang-undang keolahragaan tersebut antara lain: ${ }^{24}$

a. Manajer

Manajer adalah orang yang membantu petinju profesional dalam segala urusan administrasinya. Dalam Pasal 49 Rule and Regulation Komisi Tinju Indonesi disebutkan bahwa, terlibatnya seorang manajer dengan petinju dalam suatu kontrak harus dengan seizin dan disetujui oleh induk organisasi dalam hal ini Komisi Tinju Indonesia.

Pemilihan calon lawan tanding seorang petinju profesional juga dilakukan oleh seorang manajer. Manajer juga yang menangani kontrak pertandingan dan segala administrasinya termasuk bayaran seorang petinju sebelum dan sesudah bertandingan. Jadi dapat dikatakan baik atau buruknya manajemen yang menaunginya.

${ }^{24} \mathrm{WBC}$, Rules and regulations. 


\section{b. Promotor}

Menurut pengertian dari Pasal 1 rules and regulations Komisi Tinju Indonesia, promotor adalah badan hukum atau gabungan perkumpulan atau perorangan yang menyelenggarakan promosi pertandingan atau pertunjukan tinju secara teratur atau swaktuwaktu. Dari pertandingan tersebut dapat disimpulakan bahwa pengertian promotor adalah sama dengan penyelenggara olahraga yang syarat-syaratnya diatur dalam Pasal 51 ayat (1) sampai dengan ayat (4) undang-undang keolahragaan yang mengatur: ${ }^{25}$

Ayat (1) :

Penyelenggara kejuaraan olahraga wajib memenuhi persyaratan teknis kecabangan, kesehatan, dan ketentuan daerah setempat;

Ayat (2) :

Penyelenggara kejuruan olahraga yang mendatangkan langsung massa penonton wajib mendapatkan rekomendasi dari induk organisasi cabang olahraga yang bersangkutan dan memenuhi peraturan perundang-undangan;

Ayat (3) :

Penyelenggara kejuruan olahraga sebagaimana dimaksud pada ayat (2) wajib memiliki penanggungjawab kegiatan;

Ayat (4) :

Setiap orang dan/atau badan hukum asing dapat menyelenggarakan kejuaraan lahraga di Indonesia dalam bentuk kemitraan dengan induk organisasi cabang olahraga nasional.

Dari dua pengaturan tersebut secara ringkas dapat disimpulkan tugas dari promotor adalah menyelenggarakan pertandingan termasuk mengurus segala macam administrasi baik denagn induk organisasi maupun dengan manajer petinju profesional yang akan ditandingkan dengan syarat-syarat yang diatur dalam Pasal 51 ayat (1) sampai dengan ayat (4) undang-undang keolahragaan.

c. Inspektur Pertandingan

Dalam Pasal 14 Rules and Regulations Komisi Tinju Indonesia disebutkan bahwa, inspektur pertandingan merupakan orang yang ditunjuk oleh komisi sebagai pengawas dan pengendali dalam menyelenggarakan sebuah pertandingan tinju profesional. Inspektur

${ }^{25}$ Departemen RI, Undang-Undang Keolahragaan Nomor 3 Tahun 2005. Sistem Keolahragaan Nasional, 16. 
pertandingan merupakan orang yang berwenang untuk menunjuk petugas dalam pertandingan yang meliputi wasit, hukum, dokter ring, pencatat waktu, pencatat hasil, dan petugas kamar ganti. Sebagai pengawas dan pengendali suatu pertandingan inspektur pertandingan merupakan filter atau penyeleksi terakhir yang dapat memberikan ijin seorang petinju yang akan bertanding untuk dinyatakan layak atau tidak untuk menjalani pertandingan setelah menerima rekomendasi dari dokter yang memeriksa.

d. Wasit

Merupakan petugas utama yang mengawasi jalannya pertandingan di atas ring. sebelum pertandingan dimulai wasit harus benar-benar memeriksa kelengkapan masing-masing petinju seperti balutan dan sarung tinju untuk memastikan tidak ada benda berbahaya yang dapat membahayakan lawannya.

Kekuasaan wasit berdasarkan Pasal 59 rules and regulations di atas ring adalah mutlak dalam artian tidak ada satu pun pihak yang mengganggu dan memberhentikan pertandingan kecuali wasit. Wasit dapat menghentikan pertandingan jika menilai salah satu petinju sudah tidak mampu melanjutkan pertandingan. Dengan demikian dapat dikatakan di tangan wasitlah nasib seorang petinju digantungkan.

e. Hakim

Menurut Pasal 57 rules and regulations peran hakim dalam sebuah pertandingan tinju bertugas untuk memberikan penilaian kepada petinju yang bertanding disetiap rondennya. Hukum juga berperan mambantu wasit dalam memberikan penilaian terhadap petinju yang bertanding unatuk menentukan hasil dari suatu pertandingan.

f. Dokter Ring

Dokter ring dalam pertandingan tinju bertugas untuk memeriksa kondisi kesehatan petinju yang akan bertanding. Hasil dari pemeriksaan tersebut selanjutnya diserahkan kepada inspektur pertandinagn sebagai rekomendasi, apakah petinju yang akan bertanding benar-benar siap dari segi fisik dan kesehatannya.

Menurut Pasal 56 rules and regulations, pada saat pertandingan berlangsung, dokter ring harus berada di sisi ring sepanjang pertandingan, dan sesudah pertandingan akan memeriksa 
kondisi petinju setelah menjalani pertandingan untuk memastikan kondisi kesehatan petinju. Apabila dokter ring dalam sebuah pertandingan menilai ada salah satu petinju yang tidak mampu untuk melanjutkan pertandingan, maka dokter ring harus menyampaikan pendapatnya tersebut kepada inspektur pertandingan untuk diteruskan kepada wasit yang bertugas.

\section{Beberapa Perbuatan yang Menyebabkan Terjadinya Kematian}

Terjadinya kasus kematian seorang petinju profesional yang meninggal dunia akibat bertanding biasa disebabkan karena banyak faktor. Menurut Joko Tetuko, banyaknya kasus kematian petinju saat bertanding bisa disebabkan oleh beberapa hal yakni:

1. Petinju yang akan bertanding sudah lama tidak bertanding dan tidak melakukan latihan rutin secara intensif menjelang pertandinganya. ${ }^{26}$

2. Petinju yang akan bertanding ketika menjalanin latihan dengan memakai lawan (Sparring Patner) tidak menggunakan pelindung kepala (Head Glove), sehingga ketika bertanding petinju tersebut sudah mengalami cidera di kepalanya.

3. Sasana-sasana memaksakan petinju yang kurang mampu dan belum siap bertanding untuk bertanding.

Selain itu menurut Eddy Pirih, banyaknya kejadian kematian petinju akibat bertanding dikarenakan ada pemalsuan terhadap lisensi bertinju atau yang sering disebut buku hitam yang berisi catatan rekor pertandingan, data petinju, dan komentar dokter setelah pertandingan sebelumnya. ${ }^{27}$ Pemalsuan terhadap buku hitam tersebut bisa terjadi karena kurang telitinya inspektur pertandingan ketika memeriksa kelengkapan administrasi petinju yang akan bertanding.

Dari beberapa penyebab tersebut bisa diartikan bahwa kemampuan managerial dari sasana yang menaungi petinju tersebut tidak bagus. Sasana yang bagus haruslah mengutamakan keselamatan dan prestasi petinjunya sebagai prioritas karena memang manager dibayar untuk hal tersebut. Tinju merupakan olahraga yang berisiko tinggi dan keras, oleh karenanya diperlukan fisik dan stamina serta mental bertanding yang baik untuk menjalani sebuah pertandingan tinju. Untuk

\footnotetext{
${ }^{26} \mathrm{http} / / \mathrm{www} . \mathrm{d}$-infokom-jatim.go.id.php/id=362 2009- 04-25 (18:0022)

${ }^{27} \mathrm{http} / /$ www.kompas.co.id/kompas-cetkan/0402/28/or/882828.htm.
} 
mendapatkan kondisi fisik dan stamina serta mental tanding yang baik haruslah dilalui dengan latihan yang intensif minimal tiga bulan sebelum pertandingan serta diberi arahan dan pengawasan pelatihan yang baik pula. Kurangnya persiapan yang disebutkan di atas akan berakibat kepada buruknya kondisi si petinju ketika akan melakukan pertandingan. Seorang petinju yang bertanding dengan persiapan yang minim, berakibat pada ketidakmampuan untuk memukul lawan dengan baik dan tidak mampu menghindari pukulan dengan baik atau dengan kata lain tidak mempunyai naluri untuk bertanding. Jika persiapan petinju lawan lebih baik, secara teoritis pukulannya banyak yang masuk dan bisa menyebabkan cedera atau kemungkinan besar berakibat kematian pada petinju yang persiapannya minim. ${ }^{28}$

Jika manager tidak melaksanakan kewajiban di atas yaitu mengutamakan keselamatan dan prestasi petinju, dengan menerima kontrak pertandingan dengan waktu yang kurang ditentukan, yakni minimal tiga bulan, atau memaksakan petinju yang belum siap secara fisik dan mental untuk bertanding, maka dapat dikatakan bahwa manager tersebut telah dengan sengaja melalaikan kewajibannya, sehinga menyebabkan hilangnya nyawa seseorang, jika dalam pertandingan tersebut petinju yang dimanageri olehnya meninggal dunia.

\section{Pertanggungjawaban Pidana terhadap Kematian Petinju akibat Kealpaan Penyelenggara Menurut KUHP}

Pada umumnya, sengaja adalah menghendaki, sedangkan culpa tidak dihendaki. Culpa adalah suatu bentuk kesalahan yang ringan, itulah sebabnya ancamannya lebih ringan jika dibandingkan dengan tindak pidana yang dilakukan dengan sengaja. ${ }^{29}$

Dalam ilmu pengetahuan hukum pidana, masalah pertanggungjawaban pidana dihubungkan dengan ada atau tidak adanya unsur kesalahan dalam melakukan suatu tindakan, sebagaimana asas "Geen Straf Zonder Schuld; Actus Non Facit Reum Nisi Mens Sir Rea" atau "tidak dipidana jika tidak ada kesalahan". Secara yuridis, seorang dapat dikatakan telah memenuhi unsur kesalahan apabila ${ }^{30}$ :

\footnotetext{
${ }^{28}$ M. Shobari (pelatih sasana Bung Karno Boxing Camp Blitar), Wawancara, 8 Juni 2009.

${ }^{29}$ Bambang Poernomo, Asas-Asas Hukum Pidana (Yogyakarta: Ghalia Indonesia, 1985), 134.

${ }^{30}$ lbid., 141.
} 
1. Telah melakukan perbuatan pidana.

2. Mampu bertanggung jawab.

3. Mempunyai bentuk kesalahan.

4. Dan tidak adanya alasan pemaaf.

Istilah kesalahan berasal dari kata schuld yang sampai sekarang belum resmi diakui sebagai istilah umum yang mempunyai pengertian pasti.

Sedangkan mengenai batasan kesalahan ini para hukum memberi definisi yang berbeda-beda di antaranya;

1. Menurut Mazeer, kesalahan adalah suatu keadaan psychologis yang oleh penilai hukum pidana ditentukan sebagi perbuatan yang keliru dan dapat dicela. ${ }^{31}$

2. Menurut Wirjono Prodjodikoro mengatakan bahwa kesalahan merupakan suatu macam kesalahan dari pelaku tindak pidana yang tidak seberat seperti kesengajaan yaitu kurang hati-hati sehingga akibat yang tidak sengaja terjadi. ${ }^{32}$

Dari definisi di atas dapat dijelaskan bahwa sikap batin dari sesorang pelaku kejahatan itu bukanlah sengaja dan bermaksud untuk melakukan perbuatan yang dilarang, akan tetapi hanya karena kesalahannya sewaktu dia berbuat sehingga dapat menimbulkan larangan tersebut.

Di dalam suatu masyarakat sudah dapat dipastikan orang baik dan orang jahat hidup bersama-sama. Untuk keperluan itu, undang-undang harus dibuat sedemikian rupa agar dapat menjamin kepentingan manusia dalam hidup bermasyarakat.

Kesalahan tidak mungkin ada tanpa melakukan perbuatan yang bersifat melawan hukum atau undang-undang. Dengan kata lain, kesalahan tidak mungkin ada tanpa perbuatan pidana. Di dalam pidana, fiscal tidak memerlukan dasar kesalahan asalkan ada orang melanggar larangan dan sesuai dengan bunyi rumusan cukup untuk memberikan pidana. ${ }^{33}$

Mengenai hal pelanggaran dalam KUHP adalah perbuatan tentang kejahatan. Perbuatan yang dilakukan itu dengan sengaja atau dengan kelalaian yang berat perlu diselidiki tentang kesalahan si

\footnotetext{
${ }^{31}$ Andi Hamzah, Asas-Asas Hukum Pidana (Jakarta: PT Rineka Cipta, 1994), 129.

${ }^{32}$ Wirjono Prodjodikoro, Asas-Asas Hukum Pidana di Indonesia., 61.

${ }^{33}$ Bambang Poernomo, Asas-Asas Hukum Pidana, 150.
} 
pembuat. Terjadinya kasus kematian seorang petinju profesional, yang meninggal dunia akibat bertanding biasa disebabkan karena banyak faktor. dan juga banyaknya kejadian kematian petinju akibat bertanding dikarenakan ada pemalsuan terhadap lisensi bertinju atau yang sering disebut buku hitam yang berisi catatan rekor pertandingan, data petinju, dan komentar dokter setelah pertandingan sebelumnya. ${ }^{34}$

Pemalsuan terhadap buku hitam tersebut biasa terjadi, karena kurang telitinya inspektur pertandingan ketika memeriksa kelengkapan administrasi petinju yang akan bertanding. Dari beberapa penyebab tersebut bisa diartikan bahwa kemampuan managerial dari sasana yang menaungi petinju tersebut tidak bagus. Sasana yang bagus haruslah mengutamakan keselamatan dan prestasi petinjunya sebagai prioritas karena memang manager dibayar untuk hal tersebut.

Ketentuan hukum pidana yang dapat diterapkan adalah ketentuan yang terdapat dalam KUHP, dengan mengadakan penafsiran hukum secara ektensif. Mengingat pembahasan tulisan ini adalah membahas pertanggungjawaban pidana terhadap kematian petinju akibat bertanding, maka pembahasannya berkaitan dengan salah satu kepentingan yang dilindungi oleh hukum pidana yaitu nyawa manusia, baik itu yang dilakukan dengan kesengajaan ataupun dengan kelalain. Seperti yang diatur dalam XIX KUHP dan Bab XXI KUHP bukanlah merupakan delik aduan, akan tetapi delik biasa, sehingga aparat penegak hukum dalam hal ini kepolisian, kejaksaan, dan kehakiman dapat bertindak untuk mewakili negara, jika ada pelanggaran atas aturan tersebut walau tanpa permintaan dari korban ataupun dari pihak keluarga korban. Selain itu pada pasal 28 ayat (1) Undang-undang Nomor 4 tahun 2004 tentang kekuasaan kehakiman diatur bahwasanya, hakim wajib menggali, mengikuti dan memahami nilai-nilai hukum dan rasa keadilan yang hidup dalam masyarakat ${ }^{35}$.

Beberapa ketentuan dalam KUHP yang dapat diterapkan atas dugaan telah terjadinya perbuatan pidana yang telah dilakukan oleh manager dari petinju yang meninggal adalah diatur dalam Bab XXI KUHP tentang "Menyebabkan mati atau luka-luka karena kealpaan"

\footnotetext{
${ }^{34} \mathrm{Http} / /$ www.kompas.co.id/kompas-cetkan/0402/28/or/882828.htm.

${ }^{35}$ Undang-Undang Nomor 4 tahun 2004 tentang Kekuasaan Kehakiman
} 
khususnya pada pasal 359 KUHP dan dalam Bab XII tentang pemalsuan surat khususnya pada pasal 263 ayat (1) KUHP. ${ }^{36}$

Dalam pasal 359 KUHP dan dalam bab XII tentang pemalsuan surat khususnya pada pasal 263 ayat (1) KUHP.

Dalam pasal 359 KUHP mengatur bahwa :

"Barang siapa karena kelalainya atau kesalahanya menyebabkan orang lain mati, diancam dengan pidana penjara paling lama lima tahun atau pidana kurungan paling lama satu tahun." ${ }^{37}$

Sedangkan dalam pasal 263 ayat (1) KUHP diatur:

"Barang siapa membuat surat palsu atau memalsukan surat yang dapat menimbulkan hak perikatan, atau pembebasan utang, atau yang di peruntukan sebagai bukti dari pada suatu hal dengan maksud untuk memakai atau menyuruh orang lain memakai surat tersebut, seolah-olah isinya benar dan tidak palsu, di ancam jika pemakain surat tersebut dapat meninbulkan kerugian, karena pemalsuan surat, dengan pidana paling lama enam tahun..$^{38}$

Untuk dapat dikenakan kedua pasal tersebut di atas, seorang manager haruslah terlebih dahulu terbukti memenuhi unsur-unsur yang terdapat di dalam kedua belah pasal tersebut. Pada pasal 350 KUHP ditentukan unsur-unsur antara lain:

1. Barang siapa

2. Karena kesalahannya (kealpaanya)

3. Menyebabkan orang lain mati. ${ }^{39}$

Unsur yang pertama adalah unsur barang siapa, dalam hal ini unsur barang siapa pengertianya sangat luas karena dalam pasal 359 KUHP tidak diberikan batasan unsur barang siapa sehingga siapapun dapat dikenakan pasal 359 KUHP jika dapat dibuktikan oleh melanggar pasal ini. Karena yang menjadi perhatian dalam hal ini adalah manager dari petinju yang meninggal akibat bertanding maka dapat dikatakan manajer tersebut telah memenuhi unsur barang siapa dalam pasal 359 KUHP

Unsur yang kedua dan merupakan unsur yang paling penting adalah unsur kesalahan atau kelalain. Dalam hal ini manager dapat dikatakan telah memenuhi unsur karena kelalaiannya menerima kontrak pertandingan dengan waktu yang kurang dari yang ditentukan dan tetap

\footnotetext{
${ }^{36}$ Badan Pembinaan Hukum Nasional (BPHN). KUHP dan KUHAP, 120.

${ }^{37}$ R. Soesilo, Kitab Undang-Undang Hukum Pidana (KUHP) (Bogor: Politika, 1996), 248.

${ }^{38}$ Ibid., 195.

${ }^{39}$ Ibid., 244.
} 
memaksa petinju yang belum siap secara fisik dan mental. Sekalipun dalam tindakannya tersebut, kemungkinan akan terjadi akibat yang tidak diinginkan yaitu terjadi kematian petinju, namun dia tetap melaksanakan kehendak tersebut dari pada membatalkanya dikarenakan pelaku percaya bahwa akibat yang melekat pada tindakanya ini masih dapat dihindari atau dicegah

Bentuk dari kelalaian yang dilakukan oleh manager tersebut adalah kelalaian yang dilakukan dengan sadar atau biasanya disebut luxuria.

Menurut Jan Ramellink, culpa atau kelalaian tersebut dianggap ada apabila pelaku sudah memperhitungkan kemungkinan munculnya akibat dari tindakannya, namun dia percaya masih bisa menghindar dan mencegahnya. ${ }^{40}$ Jadi unsur kelalaiannya dalam hal ini sudah terpenuhi.

Unsur selanjutnya adalah menyebabkan kematian orang lain. Dalam hal ini terjadinya kematian pada petinju akibat bertanding merupakan pemenuhan dari unsur tersebut. Hilangnya nyawa petinju akibat tidak siapnya petinju dalam menjalani sebuah pertandingan yang diakibatkan perbuatan managernya menerima kontrak dengan waktu yang sangat minim adalah pemenuhan dari semua unsur yang ada dalam pasal 359 KUHP.

Selanjutnya unsur yang harus terpenuhi agar seorang manager dapat dikenakan pasal 263 ayat (1) KUHP adalah ${ }^{41}$ :

1. Barangsiapa:

2. Membuat surat palsu atau memalsukan surat.

3. Yang di peruntukan sebagai bukti dari suatu hal;

4. Dengan maksud untuk memakai surat tersebut seolah-olah isinya benar;

5. Dapat menimbulkan kerugian;

Unsur pertama kali yang harus di penuhi adalah memalsukan surat yang di peruntukan sebagai alat bukti dari sesuatu hal yang dapat menimbullkan kerugian.

Menurut R. Soesilo, yang dapat sebagai surat adalah sebagai jenis surat yang dapat di gunakan sebagai suatu keterangan bagi suatu perbuatan. ${ }^{42}$

\footnotetext{
${ }^{40}$ Jan Ramelink, Hukum Pidana, 155.

${ }^{41}$ R. Soesilo, Kitab Undang-Undang Hukum Pidana (KUHP), 195.

${ }^{42}$ Ibid, 196
} 
Dalam hal ini yang dipalsukan adalah buku rekor bertanding atau sering disebut buku hitam seorang petinju yang di dalamnya berisi buku rekor bertanding dan juga hasilnya dari komisi dan juga catatan dari dokter yang bertugas pada pertandingn sebelumnya.

Pemalsuan ini biasanya dilakukan apabila dalam pertandingan sebelumnya ada catatan atau komentar dari dokter ring yang bertugas pada waktu itu bahwa petinju tidak boleh bertanding dalam interval waktu tertentu. Ketika ada tawaran bertanding dalam interval waktu istirahat yang ditentukan oleh dokter tersebut, maka para manager tersebut biasanya memalsukan komentar dokter pada pertandingan sebelumnya agar petinju bisa bertanding. Apabila penyelidikannya kemudian manager terbukti melakukan dua pelanggaran tersebut maka bisa dikenakan kedua pasal tersebut yaitu pasal 359 KUHP tentang kelalaian menyebabkan orang mati dan pasal 263 ayat (1) KUHP tentang pemalsuan surat. Perbuatan pidana yang dilakukan oleh manager tersebut merupakan pembarengan perbuatan pidana, dalam ilmu hukum pidana disebut dengan Concurcus Realis yang berarti serangkain perbuatan pidana yang berdiri sendiri yang dilakukan oleh seorang pelaku dan diadili sekaligus. ${ }^{43}$

Dokter ring juga dapat dikenakan pasal 359 KUHP tentang kelalain yang menyebabkan orang lain mati apabila sebelum pertandingan dilaksanakan memberikan rekomendasi yang salah. Pada pasal 359 KUHP tersebut dapat dikenakan dokter ring apabila dia salah dalam memberikan rekomendasi tentang kelayakan seorang petinju dalam suatu pertandingan. Kesalahan rekomendasi berarti juga dia salah mendiaknosa petinju untuk bertanding. Jadi pasal 359 baru dapat dikenakan kepada dokter ring ketika dia merekomendasiakan seorang petinju untuk bertanding, dan kemudian petinju tersebut meninggal akibat bertanding, yang hasil pemeriksaan selanjutnya baru diketahui bahwa petinju tersebut tidak dalam kondisi layak tanding.

Pada masalah pemalsuan buku rekor tanding tinju, apabila mengakibatkan kurang telitinya inspektur pertandingan yang memeriksa dan kemudian terjadi kematian pada petinju yang buku rekornya dipalsukan dalam sebuah pertandingan tinju, maka inspektur tersebut dapat di kenakan pasal yang diatur dalam Bab XXI KUHP tentang kematian orang lain karena kealpaan khususnya pasal 359 KUHP.

${ }^{43}$ Didik Endro Porwoleksono, Hanh Out Hukum Pidana (2003), 43. 
Pasal tersebut dapat di junctokan ke dalam pasal 361 KUHP yang mengatur jika kejahatan yang diterangkan dalam bab ini dilakukan dalam menjalankan suatu jabatan atau pencarian, maka hukuman pidananya ditambah sepertiga dan yang bersalah dapat dicabut haknya untuk menjalankan pencarian dalam mana dilakukan kejahatan dan hakim memerintahkan supaya putusannya diumumkan. ${ }^{44}$

Inspektur pertandingan dapat dikenakan pasal tersebut dikarenakan inspektur pertandingan bertugas sebagai filter terakhir yang dapat menentukan bisa atau tidaknya seorang petinju dapat bertanding dengan cara memeriksa kelengkapan administrasi petinju yang akan bertanding yang meliputi buku rekor dan hasil pemeriksaan kesehatan. Apabila kemudian terbukti bahwa karena kurang teliti memeriksa buku rekor petinju yang dipalsukan tersebut, maka inspektur pertandingan dapat di kenakan pasal 359 KUHP dijuncto pasal 361 KUHP tentang mengakibatkan matinya orang lain karena kealpaan dalam menjalankan pekerjaan.

Selain faktor-faktor yang telah disebutkan di atas, terjadinya kematian petinju akibat bertanding adalah disebabkan pukulan lawan tanding dan kurang sigapnya wasit yang memimpin pertandingan. Pukulan lawan tanding dalam hal ini dibedakan menjadi dua yaitu: ${ }^{45}$

1. Pukulan di daerah dan cara yang legal.

2. Pukulan di daerah dan cara yang ilegal.

Mengenai daerah tubuh mana yang merupakan daerah legal dan ilegal dalam pertandingan tinju profesional tidak dijelaskan secara rinci dalam rules and regulation. Dalam pasal 75 rules and regulation hanya dijelaskan mengenai bentuk-bentuk pelanggaran keras yang dilarang untuk dilakukan dalam pertandingan tinju. Bentuk-bentuk pelanggaran tersebut adalah: $:^{46}$

1. Memukul di sebelah bawah sabuk;

2. Memukul lawan yang sedang bangkit dari jatuh;

3. Memegang lawan dengan satu tangan dan memukulnya dengan tangan yang lain;

4. Memegang atau dengan sengaja terus mendekap;

\footnotetext{
${ }^{44}$ R. Soesilo, Kitab Undang-Undang Hukum Pidana (KUHP), 249.

${ }^{45}$ M. Shobari (pelatih sasana putra Bung Karno Boxing Camp Blitar), Wawancara, 8 juli 2009.

${ }^{46}$ WBC, Rules and Regulations. 10.
} 
5. Mendorong lawan keliling ring atau ke arah tali ring untuk memikul lawan yang tanpa daya karena lawan menyandar ke tali ring dan tidak jatuh;

6. Menggumul dan berbuat kasar di tali ring;

7. Menyeruduk dengan kepala;

8. Dengan sengaja jatuh tanpa dipukul dengan maksud menghindar pukulan lawan;

9. Dengan sengaja memukul tubuh sebelah atas ginjal;

Pengaturan dalam pasal tersebut adalah merupakan adopsi rules and regulation badan tinju dunia World Boxing Council (WBC). Adanya aturan tersebut adalah untuk menghindari resiko cidera pada pertandingan tinju profesional, karena menurut pandangan medis jika harus melakukan pertandingan tinju dengan menggunakan teknik pelanggaran seperti di atas, maka besar kemungkinan timbul resiko cidera atau bahkan kematian petinju lawan ${ }^{47}$. Dalam kenyataan teknisnya, apabila salah satu petinju menggunakan tekhis pelanggaran tersebut akan dikenakan sanksi organisasi mulai dari yang ringan yaitu dikalahkan dengan cara didiskualifikasi, sampai sanksi yang terberat yaitu sekorsing.

Dari keterangan di atas, secara a contrario dapat diartikan jika seorang petinju yang bertanding dengan tidak menggunakan cara-cara yang dilarang, maka dapat diartikan petinju tersebut telah menggunakan cara yang dibenarkan. Olahraga tinju profesional merupakan olahraga yang penuh resiko. Dalam suatu pertandingan banyak sekali terjadi saling memukul lawan tanding, yang sangat rentan terhadap cedera atau bahkan kematian. Ketika dua orang petinju sepakat melakukan pertandingan dengan syarat-syarat yang ditentukan, maka dapat diartikan keduanya telah memberikan persetujuan untuk saling memukul lawannya yang berakibat dapat timbulnya rasa sakit pada keduaya.

Secara a contrario dapat ditafsirkan jika salah satu petinju tidak mengikuti peraturan yang ada dalam pertandingan tersebut, misalnya dengan cara memukul di daerah illegal seperti di atas, maka peresetujuan dalam kontes menimbulkan rasa sakit dan luka dalam olahraga tersebut sudah dilanggarnya. Karena persetujuan tersebut sudah dilanggar, maka

\footnotetext{
${ }^{47}$ Seoerjono Soekanto dan Kartono Mohamad, Aspek Hukum dan Etika Kedokteran di Indonesia (Jakarta: Grafika Pers, 1983), 75.
} 
pelakunya dapat disalahkan telah melakukan perbuatan pidana yang diatur dalam Bab XX, khususnya pasal 351 ayat (1) KUHP tentang penganiayaan yang menyatakan: ${ }^{48}$

1) Penganiayaan diancam dengan pidana penjara paling lam 2 tahun 8 bulan atau denda paling banyak Rp tiga ratus rupiah.

2) Jika perbuatan mengakibatkan luka-luka berat yang bersalah dikenakan pidan penjara lima tahun.

3) Jika mengakibatkan mati, dikenakan pidana penjara paling lama tujuh tahun.

4) Dengan penganiayakan disamakan dengan sengaja merusak kesehatan.

5) Percobaan melakukan kejahatan ini tidak dipidana.

Penganiayan menurut KUHP merupakan suatu "perbuatan yang disengaja untuk membuat cedera yang tidak didasarkan pada tujuan yang diperbolehkan “49 apabila dalam pertandingan tersebut mengakibatkan kematian pada salah satu petinju yang bertanding, terhadap pelakunya dapat dikenakan pasal 351 ayat (3) KUHP.

Mengenai penyebab yang terakhir yaitu kekurang sigapan wasit dalam memimpin pertandingan, terlambatnya wasit dalam menghentikan pertandingan ketika salah seorang petinju sudah kelihatan tidak mampu lagi untuk melanjutkan pertandingan tersebut. Kekuasaan wasit ketika di atas ring di dalam suatu pertandingan yang berlangsung adalah mutlak, seperti yang sudah dijelaskan di atas. Kekuasaan yang bersifat mutlak berarti hanya bisa menghentikan pertandingan yang sedang berlangsung.

Dari memotie van toelichting (memori penjelasan), kelalaian (culpa) merupakan kebalikan murni dari kesengajaan (dolus) maupun kebetulan (casus), yang dapat dituntut dari orang yang lalai adalah kurang berfikir cermat, kurang pengetahuan, atau bertindak kurang terarah dibandingkan orang lain pada umumnya. Dari memorie van antwoord (memori jawaban) dikatakan bahwa siapa yang berbuat salah karena kelalainnya tidak menggunakan kemampuan yang dimilikinya ketika kemampuan itu harus digunakan. ${ }^{50}$

\footnotetext{
48 R. Soesilo, Kitab Undang-Undang Hukum Pidana (KUHP), 244.

${ }^{49}$ Jan Remellink, Hukum Pidana, 264.

${ }^{50}$ Ibid., 268.
} 
Jika dikaitkan dengan masalah skripsi ini mengenai adanya tindak pidana dalam sebuah pertandingan tinju yang mengakibatkan kematian pada salah satu petinju yang bertanding, rumusan yang pertama dari unsur kesalahan mengenai melakukan perbuatan pidana adalah apabila perbuatan yang dilakukan oleh manager, inspertur pertandingan, petinju lawan, dan wasit telah mencocoki rumusan masalah pasal-pasal didalam KUHP, dan ada beberapa perbuatan pidana yang terjadi dalam kasus adanya kematian petinju yang diakibatkan menjalani pertandingan. Perbuatan pidana tersebut antara lain dilakukan oleh: ${ }^{51}$

1. Manager;

2. Dokter ring;

3. Inspektur pertandingan;

4. Petinju lawan; dan

5. Wasit yang memimpin pertandingan.

Sedangkan bentuk kesalahan yang dilakukan adalah:

1) Kelalaian, yang dilakukan oleh:

a) Manager, dalam hal menerima kontrak pertandingan dengan waktu yang minim bagi petinju untuk mempersiapkan diri, bentuk kelalaianya yang dilakukan dengan sadar (Luxuria)

b) Dokter ring, jika salah memberikan rekomendasi kepada seorang petinju untuk bertanding, dan dalam pemeriksaan selanjutnya diketahuin bahwa sebenarnya petinju yang meninggal tersebut tidak layak tanding.

c) Inspektur pertandingan, dalam hal kurang teliti dalam memeriksa admnistrasi petinju yang akan bertanding.

d) Wasit yang memimpin pertandingan, dalam hal kurang sigapnya dalam menghentikan pertandingan apabila ada salah satu petinju yang tidak mampu lagi untuk melanjutkan pertandinagan.

2) Kesengajaan, yang dilakukan oleh:

a. Manager. Dalam hal memalsukan buku rekor tanding atau buku hitam agar petinju dapat bertanding meskipun petinjunya dalam interval beristrirahat.

b. Petinju lawan, dalam hal menggunakan tekhnik pelanggaran atau memukul di daerah illegal yang dapat menyebabkan cidera pada lawan atau bahkan kematian.

${ }^{51}$ Undang-Undang No 3 Tahun 2005 Tentang Sistem Keolahragaan. 
Dari unsur kesalahan yang kedua, kemampuan bertanggung jawab seseorang di kaitkan dengan kemampuan seseorang untuk membedakan antara perbuatan yang baik dan yang buruk, di mana kemampuan semacam ini berkaitan dengan faktor akal dari seseorang.

Apabila dalam melakukan perbuatannya tersebut pada pelakunya tidak ditemukan kemampuan dan kebebasan dalam bertindak dan memilih untuk melakukan atau tidak melakukan apa yang dilarang, atau justru diperintahkan oleh undang-undang, sehingga pelaku tidak menyadari bahwa tindakan tersebut dilarang dan tidak mampu memperhitungkan akibat dari tindakannya tersebut, maka tidak ada pertanggungjawaban hukum pidana yang dapat dikenakan pada pelakunya.

Jika dikaitkan dengan permasalahan di dalam tulisan ini, ketidakmampuan dalam bertanggung jawab secara pidana tersebut pada manager, inspektur pertandingan, petinju lawan, dan wasit. Hal ini dikarenakan, disyaratkan dalam rules and regulations bahwa mereka adalah warga yang terpercaya dari suatu kota, yang berarti bahwa mereka haruslah sehat secara jasmani dan rohaninya. Khusus untuk petinju profesional, untuk mendapatkan izin atau lisensi bertanding, dalam pasal 4 ayat (1) huruf B peraturan pemerintah nomer 18 tahun 1984 tentang Olahraga profesional, ${ }^{52}$ diisyaratkan bahwa untuk dapat menjadi olahraga profesional. Jadi berdasarkan uraian tersebut, mereka dapat dipastikan mampu untuk bertanggung jawab secara pidana.

Istilah kesalahan yang berasal dari kata "schuld" secara yuridis dapat di bedakan kedalam dua bentuk kesalahan, yaitu kesengajaan dan kealpaan atau kelalaian, kesengajaan dapat diartikan sebagai suatu keadaan yang mengetahui dan menginsafkan tentang sejauh mana akibat yang ditimbulkan atas suatu tindakan yang dilakukan. Dalam hal ini, kesengajaan tersebut adalah kesengajaan sebagai kemungkinan atau kesengajaan bersyarat atau yang telah di terangkan di atas.

Contoh bentuk kelalaian yang mengakibatkan petinju meninggal akibat bertanding seperti hal yang dilakukan oleh manager dari sasana Mirah Selver dari Bali adalah petinju yang bernama Akbar Maulana dari sasana Mirah Silver dari Bali, yang pada waktu itu bertanding melawan Budiarso dari sasana Akas BC Probolinggo. Dalam kasus tersebut,

\footnotetext{
52 Departemen Republik Indonesia, Peraturan Pemerintah Nomor 18 tahun 1984 tentang Olahraga Professional, 5.
} 
manager Akbar Maulana sudah mengetahui bahwa sebelum pertandingan dilaksanakan, kondisi fisik petinju tidak memungkinkan untuk menjalani pertandingan tersebut, karena tidak terlatih secara intensif menjelang pertandingannya. Meskipun hal tersebut, manager dari Akbar Maulana tetap mengijinkan petinjunya untuk bertanding. Hasilnya, dalam pertandinggan tersebut Akbar Maulana tidak bisa mengimbangi lawannya, sehingga kemudian dia kalah technical knock out setelah dipukul bertubi-tubi oleh lawannya dan tidak lama kemudian Akbar meninggal dunia. Melihat contoh di atas dapat disimpulkan bahwa manager tersebut telah memenuhi unsur kesalahan yang mengakibatkan meninggalnya petinju tersebut. ${ }^{53}$

Dalam kasus petinju lawan yang memukul bagian tubuh lawan yang dilarang untuk dipukul dalam pertandingan tinju dapat dikenakan pasal 351 ayat (3) KUHP tentang penganiayaan yang menyebabkan matinya seseorang meskipun pelakunya adalah orang orang dari warga negara asing. Dengan ketentuan dari pasal 2 KUHP yang mengatur kekentuan pidana dalam perundang-undangan Indonesia, diterapkan bagi setiap orang yang melakukan sesuatu tindak pidana di Indonesia ${ }^{54}$. Dengan peraturan tersebut, petinju lawan yang terbukti menganiaya yang menyebabkan kematian dapat dihukum berdasarkan hukum pidana Indonesia.

Kealpaan atau kelalaian merupakan ketidaktelitian dan tidak berhati-hati di dalam kealpaan sikap batin pelaku tidak menghendaki atau tidak menyetujui adanya hal yang terlarang tersebut, namun oleh karena kesalahanya, terjadi kekeliruan yang mengakibatkan terjadinya hal yang dilarang tersebut. Dalam hal ini, kelalain tersebut dilakukan oleh inspektur pertandingan yang lalai dalam memeriksa buku rekor petinju yang akan bertanding dan dilakukan oleh wasit yang lalai dalam menghentikan pertandingannya. Apabila ada sesuatu pada salah satu petinju yang sudah tidak mampu lagi untuk melanjutkan lagi pertandingan hingga berujung kematian pada petinju tersebut, maka mereka harus mempertanggungjawabkannya.

Contoh kontrak kejadian yang merupakan kelalaian inspektur pertandingan adalah kejadian yang menimpa petinju Rahwono, meskipun tidak sampai menggakibatkan kematian. Sebelum

\footnotetext{
${ }^{53}$ Kompas, 29 Februari 2006.

${ }^{54} \mathrm{BPHN}, 3$.
} 
pertandingan dilaksanakan, inspektur pertandingan kurang jeli dalam memeriksa buku rekor Rahwono. Padahal dalam pasal 43 rules and regulations dijelaskan bahwa petinju- yang berulang kali terkena knock down akan diberhentikan sebagai petinju. Jika dalam kasus petinju Rahwono ini menyebabkan kematian, maka inspektur pertandingan akan dikenakan pasal 359 KUHP juncto pasal 361 KUHP tentang menyebabkan kematian orang lain karena kealpaan dalam melakukan npekerjaan. Jadi dalam hal ini unsur kesalahan terpenuhi.

Untuk dapat menentukan adanya unsur kesalahan dalam diri seseorang, haruslah dibuktikan bahwa atas tindakan seseorang tersebut "tidak ada alasan pemaaf" 55 yang dapat menghapuskan kesalahan dalam tindakan tersebut, selain itu juga terdapat alasan pembenaran yang dapat meniadakan sifat melawan hukum dari suatu perbuatan yang juga perlu dibuktikan.

Dalam hukum pidana dikenal tiga alasan yang dapat menghapuskan kesalahan, yaitu: ${ }^{56}$

1) Alasan pembenar.

2) Alasan pemaaf.

3) Alasan penghapus tuntutan.

Dari uraian tersebut di atas, tidak ada alasan pembenaran ataupun alasan pemaaf yang bisa meghapuskan kesalahan dari manager, petinju lawan, inspektur pertandingan, dan wasit yang bertugas, jika ada kasus kematian petinju yang meninggal dunia akibat bertanding. Jadi perbuatan mereka telah memenuhi unsur-unsur untuk dipertanggung jawabkan secara pidana.

Alasan pemaaf mungkin bisa diberikan kepada petinju lawan yang memukul di bagian tubuh yang terlarang untuk dipukul apabila terbukti pukulan yang dilakukan tersebut karena kesalahan yang dilakukan oleh petinju yang menjadi korban tersebut.

Mengenai hukuman kealpaan/kelalaian yang mengakibatkan orang lain mati dalam hukum pidana di Indonesia ada dua jenis: ${ }^{57}$

1. Hukum Pokok

a. Hukuman penjara

b. Hukuman kurungan

55 Moeljatno, Perbuatan Pidana dan Pertanggung Jawaban dalam Hukum Pidana (Jakarta: Bina Aksara, 1983), 191.

${ }^{56}$ Moeljatno, Asas-Asas Hukum Pidana (Jakarta: PT Bumi Aksara, 2003), 191.

${ }^{57}$ Andi Hamzah, Asas-Asas Hukum Pidana, 103. 
2. Hukuman Tambahan

a. pencabutan hak-hak tertentu

b. penyitaan terhadap benda-benda tertentu

c. pengumuman kepalsuan

\section{Pertanggungjawaban Pidana terhadap Kematian Petinju akibat Kealpaan Penyelenggara Menurut Hukum Pidana Islam}

Kita mengenal dua jenis olahraga kejam yaitu tinju dan gulat. Gulat yang diperbolehkan dalam Islam adalah gulat yang beraturan yang tidak memukul dan menghancurkan. Nabi mendiamkan Samurah bin Jundab dan Rafi' bin Judaij yang melakukan olahraga gulat sebelum perang uhud. Gulat menjadi haram jika dilakukan tanpa aturan dengan membolehkan segala bentuk cara untuk mengalahkan lawan, yang terkadang menyebabkan kebutaan, gegar otak, patah tulang atau kematian tanpa ada tanggung jawab. Maka Olahraga seperti ini haram secara syar'i karena firman Allah dalam surat an-Nisa' ayat 29: ${ }^{58}$

"Hai orang-orang yang beriman, janganlah kamu saling memakan

harta sesamamu dengan jalan yang batil, kecuali dengan jalan perniagaan yang berlaku dengan suka sama-suka di antara kamu.

Dan janganlah kamu membunuh dirimu, sesungguhnya Allah adalah Maha Penyayang kepadamu."

Para ulama mendefinisikan pembunuhan dengan suatu perbuatan manusia yang menyebabkan hilangnya nyawa. Sebagian fuqaha membagi pembunuhan menjadi dua bagian: Pembunuhan sengaja dan pembunuhan kesalahan..$^{59}$

Pembunuhan sengaja menurut mereka adalah suatu perbuatan dengan maksud menganiaya dan mengakibatkan hilangnya nyawa orang yang dianiaya, baik penganiayan itu dimaksudkan untuk membunuh atau tidak. Yang dimaksud dengan pembunuhan kesalahan adalah suatu perbuatan yang mengakibatkan kematian yang tidak disertai niat penganiayaan. Dasar acuan pembagian ini adalah karena al-Qur'an hanya memperkenalkan kedua macam pembunuhan ini, Allah berfirman dalam al-Qur'an surat an-Nisa' ayat; 92 telah termaktub untuk pembunuhan kesalahan, sebagai berikut:

58 Departemen Agama, Al-Qur'an dan Terjemahan (Bandung: PT. Syamil Cipta Media, 2004), 107.

${ }^{59}$ A. Djazuli, Figh Jinayah: Upaya Menaggulangi Kejahatan dalam Islam (Jakarta: Raja Grafindo Persada, 2000), 121. 
"Dan tidak layak bagi seorang mukmin membunuh seorang mukmin (yang lain), kecuali karena tersalah (tidak sengaja), dan barangsiapa membunuh seorang mukmin karena tersalah (hendaklah) ia memerdekakan seorang hamba sahaya yang beriman serta membayar diyat yang diserahkan kepada keluarganya (si terbunuh itu), kecuali jika mereka (keluarga terbunuh) bersedekah. jika ia (si terbunuh) dari kaum (kafir) yang ada perjanjian (damai) antara mereka dengan kamu, maka (hendaklah si pembunuh) membayar diyat yang diserahkan kepada keluarganya (si terbunuh) serta memerdekakan hamba sahaya yang beriman. barangsiapa yang tidak memperolehnya, maka hendaklah ia (si pembunuh) berpuasa dua bulan berturutturut untuk penerimaan taubat dari pada Allah. dan adalah Allah Maha mengetahui lagi Maha Bijaksana."60

Para ulama Hanafiyah, Syafi'iyah, dan Hanabilah membagi pembunuhan menjadi tiga macam; ${ }^{61}$

1. Pembunuhan sengaja (qatl al-'amd) yaitu; suatu perbuatan penganiayaan terhadap seseorang dengan maksud untuk menghilangkan nyawanya.

2. Pembunuhan semi sengaja (qatl shibh al-'amd) yaitu perbuatan penganiayaan terhadap seseorang dengan maksud untuk membunuh tetapi mengakibatkan kematian.

3. Pembunuhan karena kesalahan (qatl al-khata) dalam jenis ini ada tiga kemungkinan yaitu;

a. Bila si pelaku pembunuhan sengaja melakukan suatu perbuatan dengan tanpa maksud melakukan suatu kejahatan, tetapi mengakibatkan kematian seseorang; kesalahan seperti ini disebut salah dalam perbuatan (error in concrito).

b. Bila si pelaku sengaja melakukan perbuatan dan mempunyai niat membunuh seseorang yang dalam persangkaannya boleh dibunuh, namun ternyata orang tersebut tidak boleh dibunuh, keadaan ini disebut salah dalam maksud (error in objecto).

c. Bila si pelaku tidak bermaksud melakukan kejahatan tetapi akibat kelalainya dapat menimbulkan kematian, seperti seseorang terjatuh dan menimpa bayi yang berada di bawahnya hingga mati.

${ }^{60}$ Departemen Agama Rebublik Indonesia, Al-Qur'an dan Terjemahan, 121.

${ }^{61}$ A. Djazuli, Fiqh Jinayah: Upaya Menaggulangi Kejahatan dalam Islam, 124. 
Pengertian culpa atau kelalaian dalam Islam disebut istilah khata'. Definisi khata' menurut Abdul Qadir Al-Audah "Seseorang yang melakukan sesuatu perbuatan tanpa adanya maksud untuk melakukan pembunuhan terhadap orang lain, akan tetapi karena perbuatannya mengakibatkan mati”'

Menurut Sayyid Sabiq, pengertian pembunuhan karena kelalaian adalah:

"Pembunuhan karena kesalahan adalah apabila seorang mukallaf melakukan perbuatan yang diperbolehkan untuk dikerjakan, seperti menembak binatang buruan/membidik suatu sasaran, tetapi kemudian mengenai orang yang dijamin keselamatannya dan membunuhnya." ${ }^{\text {63 }}$

Kealpaan/kelalaian yang menyebabkan kematian orang lain merupakan perbuatan yang tidak disengaja. Tetapi akibat dari perbuatannya tersebut menyebabkan kematian orang lain. Dalam hukum pidana, adanya hubungan kausal antara perbuatan yang dilakukan dengan akibat kematian merupakan salah satu bentuk dari kejahatan pembunuhan.

Tujuan olahraga sebenarnya adalah perhatian terhadap jasad dengan melatih otot, menguatkan jantung dan membuat badan memiliki kemampuan tahan banting, sedangkan tujuan olahraga ini dalam pertandingan adalah melemahkan lawan dan mengalahkannya walaupun dengan menghancurkan sebagian jasad lawan.

Secara syar'i, penderitaan salah satu pemain dalam dua permainan ini tidaklah membebaskan pelaku dari tanggung jawab meskipun hal tersebut dimaafkan si penderita dan dibenarkan oleh aturan olahraga. Karena orang yang berkata kepada temannya "Bunuhlah aku!" lalu permintaannya dikabulkan, maka si pembunuh harus bertanggung jawab dan berhak mendapatkan hukuman.

Hukum Islam, dalam segi pertanggung jawaban pidana, hubungan hukuman dan pertanggungjawaban pidana, ditentukan oleh sifat keseorangan hukuman, dan ini merupakan salah satu prinsip dalam menentukan pertanggungjawaban pidana.

\footnotetext{
${ }^{62}$ Abdul Qadir Al-Audah, al-Tashrî̀ al-Jinâ'iy, Juz ll, 7.

${ }^{63}$ Ahmad Wardi Muslich, Hukum Pidana Islam (Jakarta: Sinar Grafika, 2005), 143.
} 
Firman Allah SWT dalam al-Qur'an surat al-An'am ayat 164:

"Setiap perbuatan dosa seseorang, dirinya sendiri yang bertanggung jawab. Dan seseorang tidak akan memikul dosa orang lain." ${ }^{\circ 4}$

Ayat di atas memberikan petunjuk bahwa seseorang tidak bertanggung jawab kecuali terhadap jarîmah yang telah dilakukannya sendiri, dan bagaimanapun juga seseorang tidak bertanggung jawab atas jarîmah orang lain walaupun dekatnya tali kekeluargaan atau tali persahabatan di antara keduanya.

Pertanggungjawaban pidana dikarenakan ada jarîmah (perbuatan pidana) yang dilarang oleh shara' sedangkan perbuatan jarîmah banyak motifnya sehingga pertanggungjawabannya pun bermacam-macam, ada tiga tingkatan sesuai dengan tingkatan melawan hukum.

1. Sengaja (al-'amdu)

2. Menyerupain sengaja (shibh al 'amdi)

3. Keliru (al-khata')

Dikaitkan dengan permasalahan yang ada dalam tulisan ini yaitu pertanggungjawaban pidana terhadap kematian petinju akibat kealpaan penyelenggara, unsur-unsur yang tiga di atas dapat diterapkan kepada para pihak yang terkait dalam proses awal sampai akhir dalam menyelenggarakan sebuah pertandingan tinju, untuk dimintai pertanggungjawabannya yaitu meliputi:

a. Manager;

b. Dokter ring;

c. Inspektur pertandingan;

d. Petinju lawan; dan

e. wasit yang memimpin pertandingan.

Para ulama fiqh menetapkan dua kaidah untuk menetukan apakah pelaku tindak pidana karena kesalahan dibebani pertanggung jawaban atau tidak? dua kaidah tersebut adalah sebagai berikut: ${ }^{65}$

1. Setiap orang yang membawa kemadharatan kepada orang lain harus bertanggung jawab. Jika mungkin, ia harus menghindarkannya. Seseorang dapat mampu mencegahnya, jika ia tidak dapat mampu mencegahnya secara mutlak, maka ia tidak dapat diberi sanksi.

\footnotetext{
${ }^{64}$ Departemen Agama Rebublik Indonesia, Al-Qur'an dan Terjemahan, 202.
}

${ }^{65}$ A. Djazuli, Fiqh Jinayah: Upaya Menaggulangi Kejahatan dalam Islam, 133. 
2. Segala perbuatan yang tidak diijinkan secara shara' dan perbuatan tersebut itu dilakukan juga tanpa ada darurat yang nyata, maka pelakunya dianggap melakukan kesengajaan dan harus mempertanggung jawabkan akibatnya, baik ia mampu mencegahnya ataupun tidak.

Pada dasarnya pertanggungjawaban dalam syariat Islam hanya dikenakan terhadap perbuatan sengaja dan diharamkan oleh shara' serta tidak dikenakan terhadap kekeliruan sebagai firman Allah surat al-Ahzab ayat 5 ;

"Panggillah mereka (anak-anak angkat itu) dengan (memakai) nama bapak-bapak mereka; Itulah yang lebih adil pada sisi Allah, dan jika kamu tidak mengetahui bapak-bapak mereka, maka (panggillah mereka sebagai) saudara-saudaramu seagama dan maula-maulamu. Tidak ada dosa atasmu terhadap apa yang kamu khilaf padanya, tetapi (yang ada dosanya) apa yang disengaja oleh hatimu. Allah Maha Pengampun lagi Maha Penyayang." ${ }^{\circ 6}$

Dengan demikian jika seseorang melakukan perbuatan yang tidak dilarang namun mengakibatkan sesuatu yang dilarang, maka pertanggungjawabannya dibebankan karena kelalaiannya atau kekurang hati-hatiannya dalam mengendalikan perbuatan itu. Adapun jika perbuatan itu perbuatan yang dilarang, maka dasar pembebanan pertanggungjawabannya itu karena melakukan perbuatan yang dilarang. ${ }^{67}$

Jika yang telah dilakukan oleh inspektur pertandingan, manager, wasit, dokter ring, petinju lawan, telah memenuhi unsur-unsur kesalahan yang mengakibatkan matinya orang lain dalam pertandingan tinju, maka dalam hukum pidana Ialam, para pihak yang telah disebutkan di atas dapat dikenakan dengan jarîmah pembunuhan tersalah. Hal tersebut karena adanya faktor-faktor yang mengakibatkan terjadinya pelanggaran yang dilakukan oleh manager, inspektur pertandingan, dokter ring, wasit, dan petinju lawan: ${ }^{68}$

1) Adanya perbuatan yang menyebabkan kematian.

Unsur ini prinsipnya disamakan dengan pembunuhan sengaja, dikarenakan perbuatan tersebut dilakukan oleh si pelaku dan perbuatannya tersebut dapat menimbulkan kematian. Perbedaan

\footnotetext{
${ }^{66}$ Departemen Agama Rebublik Indonesia, Al-Qur'an dan Terjemahan, 591.

${ }^{67}$ A. Djazuli, Fiqh Jinayah: Upaya Menaggulangi Kejahatan dalam Islam, 134.

${ }^{68}$ Ibid., 134-135.
} 
untuk unsur pmbunuhan tersalah dan sengaja terletak hanya pada alat yang digunakan untuk melakuakn pembunuhan

2) Terjadinya perbuatan tersebut karena kesalahan.

Unsur yang kedua inilah yang membedakan pembunuhan karena kesalahan dengan pembunuhan yang bukan kesalahan. Boleh jadi kesalahan tersebut adalah kelalaian yang dapat mengakibatkan matinya seseorang. Dikarenakan tidak ada sanksi teradap orang yang melakukan kesalahan, akan tetapi apabila kelalaian tersebut dapat menimbulkan kemadharatan terhadap orang lain, maka akan dijatuhkan sanksi atas perbuatan kesalahan tersebut. Ukuran kesalahan dalam syariat Islam adalah adanya kelalaian atau kurangnya hati- hati atau merasa tidak akan terjadi apa-apa.

3) Adanya hubungan sebab akibat antara perbuatan kesalahan dengan kematian korban.

Kematian seorang petinju akibat bertanding adanya unsur sebab akibat kesalahan dari pelaku yakni manager, dokter ring, inspektur pertandingan, petinju lawan setar wasit yang memimpin dalam suatu pertandingan tinju. Karena kesalahan tersebut menjadi sebab bagi kematian petunju tersebut.

Manager, dokter ring, inspektur pertandingan, petinju lawan setar wasit yang memimpin dalam suatu pertandingan tinju yang mengakibatkan matinya seorang petinju akibat bertanding, semuanya dikategorikan pembunuhan karena kesalahan (al-khata) dikarenakan apa yang disangkakan terhadap manager dan yang lainya, sudah memenuhi pengertian al-khata'. Pengertian al-khata' adalah terjadinya suatu perbuatan di luar kehendak pelaku, tanpa adanya maksud melawan hukum, perbuatan tersebut terjadi dikarenakan kelalaiannya atau kurang hati-hatiannya atau yang disebut khata' fi al-shakhși (kekeliruan subjektif). ${ }^{69}$

Niat dan maksud menjadi salah satu variabel yang menentukan bentuk-bentuk pembunuhan. Manager, dokter ring, inspektur pertandingan, petinju lawan serta wasit telah melakukan sebuah kelalaian yang berakibat matinya seseorang. Dimana tentang kelalaian tersebut telah dipaparkan di atas.

\footnotetext{
${ }^{69}$ Jaih Mubarok dan Enceng Arif Faisal, Kaidah Fiqh Jinayah (Bandung: Pustaka Bani Quraisy, 2004), 16.
} 
Adapun unsur yang dapat menggugurkan pertanggungjawaban pidana, tidak ditemukan terhadap manager serta yang lainya, seperti unsur tidak tahu, dikarenakan ketetapan suatu pertandingan tinju ada aturan baku yang harus ditaati tahap demi tahap. Ketika tahapan demi tahapan tersebut tidak dijalankan, maka berbagai macam konsekuensi akan terjadi. Salah satu konsekuesi yang terburuk adalah matinya seorang petinju, dan tentu seorang manager dan yang lainnya mengerti betul akan hal ini, jadi dari semula segala konsekuensi bisa terjadi namun manager dan yang lainya tetap melaksanakan suatu pertandingan tinju. berdasarkan hal tersebut, sudah jelas unsur kelalaian yang timbul dari pertandingan tersebut serta unsur tidak tahu, tidak dapat diterima untuk mengubah pertanggungjawaban pidana.

Begitu pula pengaruh lupa yang bisa menggubah pertanggungjawaban pidana, tidak dapat diterima terhadap wasit yang memimpin pertandingan. Lupa disini diartikan dengan tidak siapnya sesuatu pada waktu yang diperlukan, seperti dalam contoh kasus kematian petinju Jack Ryan yang melawan Syamsul. Sebelum dinyatakan $\mathrm{KO}$, sebenarnya pada awal ronde ke delapan pertandingan tersebut sudah harus dihentikan oleh wasit, sebab pertandingan tersebut sudah tidak seimbang, namun wasit terlambat mengghentikan pertandingan maka terjadiah musibah tersebut. Tidak siapnya wasit tersebut untuk menghentikan pertandingan pada waktunya telah dianggap lalai, jadi unsur lupa tidak bisa dijadikan alasan untuk gugurnya suatu pertanggungjawaban bagi seorang wasit.

Olahraga tinju memang digolongkan olahraga yang ekstrem. Memang terdapat unsur kerelaan menjadi sasaran pukul dari masingmasing petinju, akan tetapi kerelaan tersebut haruslah sesuai dengan aturan tinju. Hal- hal yang diatur dalam pertandingan tinju mengenai daerah pukulan yang tidak diperbolehkan diantaranya: memukul bagian perut di bawah pusar, karena dapat mengakibatkan akan terjadi hal-hal yang fatal, atau boleh jadi pukulan tersebut mengenai tempat yang vital dikarenakan posisi dari masing-masing petinju. Semisal petinju A mau memukul petiju B di bagian mukanya tapi bersamaan dengan itu, kaki dari petinju B tergelincir ke depan seketika itu juga pukulan petinju A mengenai bagian otak belakang petinju $\mathrm{B}$, di mana bagian tersebut dilarang karena dapat berakibat fatal bagi petinju lawan dan dapat mengghantarkan kematian. 
Jadi unsur kerelaan dan kekeliruan tidak akan menghapus suatu pertanggungjawaban pidana. Hukuman pokok dalam pembunuhan kesalahan adalah diyat dan kafarat. Hukuman penggantinya adalah puasa dan ta'zir dan hukuman tambahannya adalah hilangnya hak waris dan hak mendapat wasiat ${ }^{70}$;

1. Membayar diyat, diperingankan yang dibebankan atas keluarga pembunuh pelunasanya bisa di anggsur sampai 3 bulan.

2. Membayar kafarat, memerdekakan budak muslim yang tanpa cacat, bilamana pelaku pembunuhan tidak bisa merealisasikan hal ini, maka ia diwajibkan puasa 2 bulan berturut-turut.

\section{Simpulan}

Terjadinya kematian petinju bukan merupakan tujuan dari pelaku pada waktu melakukan perbuatan pidana, hanya karena kurang berhati-hati serta adanya unsur kelalaian, mengakibatkan matinya orang lain.

Konsep pertanggungjawaban pidana dalam KUHP hanya memperhatikan kepada akibat dari perbuatan yang dilakukan oleh seseorang. Terjadinya pembunuhan dengan kealpaan, di dalam teori KUHP hanya dilakukan oleh seseorang secara langsung dan kolektif. Sedangkan menurut hukum pidana Islam, yang dilakukan oleh seseorang baik secara langsung maupun tidak langsung, aktif maupun pasif, yang menimbulkan matinya seseorang harus ada pertanggungjawaban pidana. Dalam pembunuhan yang termasuk secara langsung dan aktif adalah terlibatnya manusia yaitu badan pada waktu melakukan perbuatan.

\section{Daftar Rujukan}

Audah (al-), Abdul Qadir. Al-Tashrî' Al-Jinâ'iy Al-Islâmiy. Juz II, Beirut: Dar al-Kitab al-Arabi, t.t.

Badan Pembinaan Hukum Nasional (BPHN). KUHP dan KUHAP

Depag RI. Al-Qur'an dan Tarjamahnya. Bandung: PT. Syamil Cipta Media, 2004.

Departemen Republik Indonesia. Peraturan Pemerintah Nomor 18 Tahun 1984 Tentang Olahraga Profesional

\footnotetext{
${ }^{70}$ A. Djazuli, Fiqh Jinayah: Upaya Menaggulangi Kejahatan dalam Islam, 146.
} 
Departemen RI. Undang-Undang Keolahragaan Nomor 3 Tahun 2005. Sistem Keolahragaan Nasional

Djazuli, A. Fiqh Jinayah: Upaya Menaggulangi Kejahatan dalam Islam. Jakarta: Raja Grafindo Persada, 2000.

Hamzah, Andi. Asas-Asas Hukum Pidana. Jakarta: PT Rineka Cipta, 1994.

Hanafi, Ahmad. Asas-Asas Hukum Pidana Islam. Jakarta: Bulan Bintang, 1990.

Moeljatno. Perbuatan Pidana dan Pertanggung Jawaban dalam Hukum Pidana. Jakarta: Bina Aksara, 1983.

---_---. Asas-Asas Hukum Pidana. Jakarta: PT Bumi Aksara, 2003.

Mubarok, Jaih dan Enceng Arif Faisal. Kaidah Fiqh Jinayah. Bandung: Pustaka Bani Quraisy, 2004.

Muslich, Ahmad Wardi. Hukum Pidana Islam. Jakarta: Sinar Grafika, 2005.

Najib, Emha Ainun. Bola-Bola Kultural. Yogyakarta: Prima Pustaka, 1993.

Poernomo, Bambang. Asas-Asas Hukum Pidana. Yogyakarta: Ghalia Indonesia, 1985.

Porwoleksono, Didik Endro. Hand Out Hukum Pidana, 2003.

Pradjodikoro, Wirjono. Asas-Asas Hukum Pidana di Indonesia. Bandung: Eresco, Cet 6, 1989.

Soekanto, Seoerjono dan Kartono Mohamad. Aspek Hukum dan Etika Kedokteran di Indonesia. Jakarta: Grafika Pers, 1983.

Soesilo, R. KUHP Serta Komentar-Komentarnya Lengkap Pasal demi Pasal. Bogor: Politika, 1996.

Peraturan Pemerintah No 18 tahun 1984 tentang Olahraga Profesional.

Undang-Undang No 3 Tahun 2005 Sistem Keolahragaan Nasional. Jakarta: Sinar Grafika, 2006.

Shobari, M. Wawancara. 8 Juni 2009.

Robbani, A. Wawancara. 7 Mei 2009.

WBC. Rules and Regulations.

http//2.kompas.com/ver1/olahraga/0703/22/u51240.htm 25-05-2009 
http:/www2.kompas.com/kompas-cetak/0404/06/or/953162.html

11-2009

$\mathrm{http} /$ search.jawapos.com/indeks.php?act=detail-s\&f-

sarch $=$ fadly\%20kasim\&id231884 .25 Mei 2009

http//www.d-infokom-jatim.go.id.php/id=362 2009- 04-25

Http//www.kompas.co.id/kompas-cetkan/0402/28/or/882828.h tm.

http://search.jawapos.com/indeks.php?act=detail_s\&f_search=fadly $\% 20 \mathrm{k}$ asim\&id $=231884$

http://www.jawapos.co.id/halaman/index.php?act=detail\&nid=75 15-

11-2009.

http://sports.groups.yahoo.com/group/tinju/message/615 30-10-2009

http://www.boxing-indonesia.com/2008/05/asal-mula-istilah-ring.html

30-10-2009 